\title{
Negotiating the self between past and present: narratives of older women moving towards self-employment
}

\begin{abstract}
Older people are encouraged into self-employment as a means to extend their working lives; however both age and gender are thought to constrain the capacity of individuals to take on an enterprising identity. This paper explores the narrative identity work of women over 50 contemplating a move into self-employment. It reveals how they negotiated a provisional self-employed identity in relation to an aged identity, an enterprising identity and an identity as organizational outsider. It discusses the implications of contrasting forms of engagement with these identities for the subsequent enactment of participants' business plans. The paper briefly considers the implications of its findings for the following areas: enacting and realising provisional identities; the relationship of self-employment to enterprise; and a process-based conceptualisation of age.
\end{abstract}

Keywords age, enterprise, gender, identity, narrative, self-employment 
The increased interest in age-related issues within industrialised countries reflects concerns about the demands that their rapidly ageing populations place on welfare systems. Consequently people are expected to remain economically, physically and socially active and independent for ever longer, and in this context older workers are encouraged to move into self-employment as a means to extend their working lives. In other words, older individuals are increasingly exhorted to take up the entrepreneurial self. However, as previous work has indicated, this identity is not necessarily available to everyone, and factors such as age and gender may constrain the ability to 'be'- and be seen as - entrepreneurial (Ainsworth \& Hardy, 2008).

Although self-employment amongst older workers has increased substantially, women reportedly make up only $25 \%$ of self-employed people over 50 in the UK (Bachelor, 2013). They therefore represent a target group for initiatives to encourage self-employment; this paper explores how older women who are contemplating a move into working for themselves construct provisional identities as self-employed people. Its focus is narrative identity work; how research participants applied narratives in their engagement with the tension between optimistic discourses of enterprise and discourses of age as decline. It reveals that a provisional self-employed identity was not constructed in isolation, but negotiated in relation to other available identities - comprising an enterprising identity, an aged identity and an identity as organizational outsider. It contrasts the forms of interplay found amongst these identity positions, and considers their implications for the realisation of a self-employed identity; drawing on vignettes of five women in order to reflect on their subsequent trajectories in the light of their original identity work.

The paper is structured as follows: we provide an overview, based on existing literature, of the interconnections of enterprise with age and gender, from which we extract a number of issues and questions. We explain the approach taken to address these questions; involving the 
analysis of individual narratives. We present the principal themes that emerged from this analysis, before contrasting the interplay of identity positions and the forms of engagement with age found in the accounts of five participants. We conclude with reflections on the relevance of our findings to further research and theorising in three areas: the implications of contrasting narratives of a provisional identity for its subsequent enactment; untangling the concepts of self-employment, enterprise and the enterprising self; and the role of age in identity construction, drawing on an understanding of age as a process rather than as an arbitrary and contested marker of difference.

\section{Constructing the older worker}

The concept of older age is applied to a very broad period from middle age to later life (Walker et al, 2007), with inclusion in the 'older worker' category starting as young as 40 (Bohlinger \& van Loo, 2010; Ainsworth \& Hardy, 2004), although it is most often applied to those over 50 (Loretto \& White, 2006; Riach \& Loretto, 2009; Lewis \& Walker, 2011). However grouping 50-year-olds in the same category as (say) 70-year-olds rather than with 30-year-olds makes no obvious sense except in relation to an idea of ageing as progressive decline; reflecting biological models of ageing that take chronological age as a proxy indicator of relative ability (Coupland et al, 2008). However the label 'older worker' is not applied to everybody over 50 but designates those perceived to occupy a vulnerable labour market position. Efforts to improve older people's employment prospects involve engaging with age discrimination and the stigma attached to the older worker; 'business case' arguments seek to counter ageism by countering negative stereotypes with claims regarding the positive attributes of older employees. However ascribing shared characteristics to people grouped by chronological age creates an artificial opposition between older and younger 
employee (Loretto \& White, 2006); furthermore attributes such as the supposedly superior people skills, reliability or maturity of older workers are most often applied to assert their suitability for a restricted range of low-level jobs (Riach, 2007; Ainsworth \& Hardy, 2002), involving their potential relegation into a sub-class of employee (Coupland et al, 2008).

The older worker is thus discursively constructed as a largely unattractive identity with limited opportunities for agency. Riach (2009) highlights HR managers' acknowledgement that many 50+ individuals would not recognise themselves as 'older workers' or want to be viewed as such. In contrast to other markers of diversity, older age involves distancing and denial, yet it is - as Ainsworth \& Hardy (2008, p. 403) point out - 'one version of identity with which most of us will be forced to engage at some point'.

\section{Active ageing and the enterprising self}

Accounts of how individuals should engage with growing older increasingly refer to the idea of active ageing, which seemingly offers greater possibilities of agency and empowerment. Active ageing strategies focus on older people's engagement in activities of benefit to society, with the intention of minimising their dependence on the state (Š́mová, 2010). Based on an analysis of discourses of positive ageing found in Canadian newspapers, Rudman (2006) found that continued participation in productive activity, primarily paid work, was advocated as a means to enact the identity of the active, autonomous and self-reliant 'ideal ageing individual'. This ideal is a product of neo-liberal political rationality, a core element of which is: 'the enterprising self, one who rationally projects and works towards a self-made future... ideal ageing subjects are those who... proactively work towards idealised lifestyles and subjectivities' (Rudman, 2006, p. 195). 
The emergence of 'enterprise' as a principle guiding a more individualised vision of society in which 'safety nets of community, family, mutual dependencies and social welfare are increasingly eroded' (Fenwick 2002, p. 706) has been widely discussed. The 'enterprising self', understood a 'central paradigmatic concept underpinning the rationale of new alternative work forms and relationships' (Storey et al, 2005, p. 1033), is constructed as an individual who is risk-taking, hardworking, flexible, and takes responsibility for his/her own success and failure (Storey et al, 2005; Fenwick, 2002; Ainsworth \& Hardy, 2008; Wee and Brooks, 2012). Whilst Rudman claims that active ageing discourses require of older people that they act as entrepreneurs, Ainsworth \& Hardy (2008) argue that although older workers are subject to the demands of enterprise culture, their access to the enterprising self is limited because the associated characteristics of energy and optimism are incompatible with a dominant discourse of ageing as decline. There is a tension therefore between the enterprising self as an ideal to which older people are expected to aspire, and the enterprising self as an ideal incompatible with an aged state, in so far as the latter is equated with diminishing capacities. According to Rudman (2006), the ideal ageing subject defies age and pursues youthfulness, and as Ainsworth \& Hardy (2008) concur, 'successful' ageing involves not its acceptance but minimising its assumed effects. By implication the enterprising self is primarily accessible to 'age-defying' subjects; its enactment serving as evidence of having so far resisted the ravages of age.

\section{Enterprise and gender}

The pervasiveness of enterprise discourse has led to a substantial body of research into how various groups engage with the enterprising ideal. 'Being an entrepreneur', in the narrower sense of establishing a business, can be distinguished from the broader concept of 'being enterprising'. It is in this latter sense that enterprise discourse prescribes the ideal identity of 
the 'enterprising self' who acts as an 'emancipated subject', in line with 'normative beliefs about what it means to be a worthwhile self' (Wee \& Brooks, 2012 p. 577). Despite claims that it is universally accessible 'the entrepreneurial self is not an identity that everyone can assume' (Ainsworth \& Hardy 2008, p. 391), and the extent of women's engagement with enterprise is brought into question by representations of their self-employment as problematic compared to that of men. Women comprise a minority of self-employed people in the European Union; they are more likely to own home-based businesses and work part-time; furthermore it is suggested that this picture has not changed greatly in 20 years (Marlow \& McAdam, 2013). Explanations of this state of affairs based on women's lack of entrepreneurial or business acumen are open to challenge (Ahl, 2006); instead the profile of women's enterprise reflects historical patterns of gender subordination - how 'the social devaluation of the feminine per se.... has been seamlessly mapped on to economic activities undertaken by women' (Marlow \& McAdam, 2013, pp. 117-8). Unchallenged assumptions about gender differences and women's business activity reinforce the 'masculinity inherent within the enterprise discourse' (Marlow \& McAdam, 2013, p.119).

The gendering of enterprise discourse creates the need to justify female entrepreneurship (Bruni et al 2004), informing research into how self-employed women establish the legitimacy of their businesses, and of themselves as worthwhile and productive individuals. The main point of tension derives from the way that gender relations are built into the historical separation of home and work; between the personal and professional spheres of life (Bourne \& Calás 2013; Lewis 2013; Wee \& Brooks, 2012). When self-employment is promoted as a means by which women may more easily cope with the demands of both spheres it risks making their businesses appear more marginal, because activities in the domestic sphere are not counted as 'real' work (Bourne \& Calás, 2013). 
However the enterprising self is not a singular, uncontested concept; its ambiguity and instability make it possible for self-employed people to refuse elements of the enterprising ideal that they find difficult to reconcile with their experience and aspirations (Fenwick, 2002; Storey et al, 2005). In Essers and Benschop's (2007) study, Dutch female entrepreneurs of Moroccan and Turkish origin turned the assumed disadvantage associated with their gender and ethnicity into an advantage; indicating the potential of enterprise to serve as an empowering tool for members of marginalised groups.

\section{Age, gender and the olderpreneur}

If this empowering potential derives from exploiting tensions at the boundaries of ethnicity and gender, what possibilities of constructing an entrepreneurial identity are offered by combining a gendered identity with an aged identity? Although ageism is experienced by both men and women, perceptions that women are more likely than men to experience age discrimination and to encounter it at an earlier age, underpin the concept of 'gendered ageism' (Duncan \& Loretto, 2004). It is claimed that men are offered more protection from the negativities associated with ageing; so that men in their 50s occupying powerful positions are rarely positioned in the problematic 'older worker' category (Jrynkinen and McKie, 2012).

The social systems of gender and age interact through the relations of production and reproduction; enacted through processes of family forming, child bearing and rearing and participation in employment and education (Moore, 2009; McKie et al, 2013) The effect is to produce gendered life stages - thus women's 'mid-life' involves both physiological change and altered domestic responsibilities (Austen \& Ong, 2009; Hodges, 2012). A connection between life-stage and a turn to self-employment was made by mid-life professional women in Hodges' (2012) study, who associated this stage negatively with experience of 
organizational environments as ageist, but positively with opportunities for greater autonomy and authenticity. Women managers in McKie et al's study (2013) explained their decision to become self-employed as movement into the next stage of their career - one offering escape from gendered hurdles in the workplace, but also greater flexibility and control. McKie et al (2013) formulate these accounts as women both 'opting out' (of organizational employment) and 'opting in' (to working for themselves). This formulation doesn't only apply to older women - the label 'mumpreneur' has recently gained currency as an identity through which women can combine productive economic activity with childcare. Working independently in order to achieve greater flexibility is promoted as a positive choice; albeit one that has 'adapted to the structural realities of family life and societal pressures' (Ekinsmyth, 2013, p.528). And as an identity that is aged as well as gendered - because it refers to a specific period in women's lives - then the 'mumpreneur' invites comparison with another neologism and hybrid label; that of the 'olderpreneur'.

By merging two concepts more usually regarded as incompatible, the 'olderpreneur' provides a label with which to promote older enterprise, drawing on claims that companies started by people over 50 have a better survival rate than companies started by younger people (Hart, 2007). Promoting older enterprise has become a 'potentially attractive policy option' (Kibler et al, 2012, p. 9) that can not only 'prolong the working lives of older people, reduce olderage unemployment, [and] enhance the social inclusion of older individuals', but also provide 'an activity to supplement the income or maintain the standard of living' of those without sufficient savings' (OECD, 2012, p. 2); highlighting the financial vulnerabilities of many people approaching retirement age.

Advocating self-employment to people who might not otherwise have considered it conforms to the tenets of the enterprise culture regarding the desirability and attainability of starting 
your own business. However Lewis and Walker (2011, pp. 145-7) challenge the 'naïve conceptualisation' of self-employment as a panacea with which to address the problems of an ageing population, questioning claims that older people are: 'by virtue of a number of generational progressions... in a stronger position to start a business'. The success of businesses started by older people is attributed to the experience and resources that they have acquired over their life course. However these resources, both material and non-material, are distributed very unevenly amongst the population; particularly amongst those who comprise the primary targets of policy to encourage self-employment; namely the long-term jobless of whom Kautonen et al (2008, p.89) suggest: 'the current attitudes and behaviours of the older population are not very favourable for entrepreneurship'. Less optimistic accounts of older enterprise cast doubt upon how 'entrepreneurial' are the businesses started by older people - suggesting they might simply be 'buying themselves a job' (Ainsworth \& Hardy 2008; Lewis \& Walker, 2011), or questioning their 'dynamism... because their business decisions are often driven by lifestyle choices' (OECD, 2012, p. 7).

This last comment echoes accounts of women's enterprise that suggest it is practised primarily to achieve flexibility and is insufficiently focused on growth. The perception that 'older enterprise', like 'women's enterprise' is not enterprise per se, but a minor variant, implies that age and gender combine to make older women the least likely candidates for enterprise. Yet the impact of low pay, interrupted careers and part-time working on their access to pensions and financial security means that they may have an even more pressing need than men to extend their working lives (Duncan \& Loretto, 2004).

This overview has highlighted how discourses of gender, age and enterprise interact to reproduce a series of separations - between the public and private spheres; between older and younger workers; and between older women and older men. Yet these distinctions are blurred 
by ambiguities and contradictions. The uncertainty regarding where to locate the boundary between younger and older, and the inconsistency with which the 'older' label is applied, support the argument of Yuval-Davis (2006, p. 201) that age discourses exemplify particularly well 'how categories and their boundaries are not fixed and how their social and political meanings can vary.... as well as being continually challenged and restructured'. Given this indeterminacy it may be asked whether it is possible to formulate an account of a move to working independently that is disconnected from an aged identity - to assume the mantle of enterprise unsullied by the negative connotations of older age. These negative connotations are questioned by Krekula (2007) who argues that the 'misery' perspective on women's ageing omits the dimension of personal development, and the possibility that women might associate older age with new experiences, values and self-confidence. Her argument suggests an account of self-employment that does involve adopting an aged identity - but one couched in more positive and optimistic terms. The notion of an ideological fit between the ideal ageing subject and the enterprising self (Rudman, 2006) brings into play how older individuals deploy these idealised subjectivities in explaining their interest in selfemployment.

It is claimed that women's enterprise is compromised when they prioritise the demands of the personal sphere over those of the professional sphere (Wee and Brooks, 2012); the distinction between public and private domains forms the axis around which gender differences are constructed. Age, in contrast, 'represents the dimension of time and the life cycle' (YuvalDavis 2006, p. 201). This conceptualisation suggests a direction for the study of age moving beyond the preoccupation with decline; exploring instead the negotiation of identity in relation to the passage of time. Krekula (2007) proposes that research into age/gender intersections should focus on the individual, in order to avoid generalisations about 'older women' as a homogenous group, and to enable consideration of the interplay of different 
identity positions, including class and ethnicity, in shaping life experiences and possibilities of being and acting in later age. The next section explains the perspective that we applied to the analysis of individual identity construction.

\section{Constructing identity through narratives}

Whereas most existing research into self-employment, gender and age draws on selfemployed women's retrospective accounts, the subjects of this study were women for whom it represented an untried path, who were thus engaged in explaining and justifying their suitability to make such a move - both to others and to themselves. This engagement constituted identity work - activities undertaken to form, repair, maintain, strengthen or revise their sense of self (Alvesson et al, 2008; Ibarra \& Barbaslescu, 2010). Identity work is necessarily more intense for people in transition, as they endeavour to achieve 'continuity between who they are and who they are becoming' (Ibarra \& Barbaslescu, 2010, p.136). Ibarra \& Barbaslescu (2010) propose that identity transitions that depart from established conventions demand greater justification to both self and others, bringing into question how those not traditionally associated with enterprise establish a connection between past identities and the self-employed person they mean to become.

Although they require constant reworking, identities are not infinitely malleable but are constrained by structural factors and negotiated within arenas of unequal power (Riach \& Loretto, 2009; Moore, 2009). An over-emphasis on fragmentation neglects 'consideration of accounts of self-identity across time' (Riach \& Loretto 2009, p.106). The interplay of time with continuity and change is well expressed in the observation of Ricoeur (1991, p.190), that: 'we say of an oak it is the same thing from the seed to the tree in the prime of life' - that despite having changed over time, the integrity of the individual self is maintained. The 
primary medium through which we engage with continuity and change in relation to the self is narration - showing or telling events in storied form (Cobley, 2001). Because 'in telling the story of my life, I make sense of past events and create a person living in the present as a continuation of that story' (Gabriel et al, 2010, pp.1692-3), self-narratives are understood as 'both expressive of and constitutive of identity' (Ibarra \& Barbulescu, 2010, p.135).

Through narratives people seek to construct recognisable selves (Chase, 2008) - recognisable to the self as authentic, and to others as valid. An authentic self is internally experienced as consistent and genuine (Lewis, 2013); questions of validity concern the credibility of an individual's claims to the identity to which she aspires. Events and turning points form the raw material from which personal narratives are constructed; however individual experience may encompass unwanted events that challenge optimism and undermine self-worth. Based on a study of unemployed people over 50 Gabriel et al (2010) argue that coming to terms with events such as redundancy is helped by stories in which narrators construct new identities for themselves as people able to 'move on'. In contrast, older and disabled unemployed people in Riach and Loretto's (2009) study drew on past working identities to support their sense of self-worth and to resist negative stereotypes of the workshy unemployed.

The reparative function of identity work may thus involve resisting imposed or unwanted identities; Walker et al. (2007, p. 45) found that older women workers expressed an internal conflict between their changing outward appearance and the 'mental and spiritual sense that they had not changed over time' in order to avoid being labelled 'too old'. Discourses of age that place younger and older people into separate categories imply a differentiation between the self in the past and the self in the present, raising the question: how far does narrating a changed self necessarily involve also narrating an aged self? It may be further asked: how do older women negotiate between continuity and change when accounting for their present 
intention to pursue self-employment? To what extent does the self that emerges from their narratives embrace or refuse elements of both age and enterprise? What are the implications of these engagements for the construction of a self recognisably capable of enacting an identity that is as yet unrealised?

\section{Research study and method of enquiry}

We draw on material gathered from a wider, longitudinal study of older women entering selfemployment that aimed to develop understanding of the experiences, priorities and strategies of a group rather neglected in the entrepreneurship literature, and to uncover relevant structural and institutional factors that supported or hindered their progress. The research subjects comprised older participants on two women-only courses run by the Centre for Microenterprise, London Metropolitan University between 2007 and 2009. The courses aimed to assist women with plans for self-employment to establish sustainable businesses. They were free to participants and were heavily over-subscribed. The principal method of enquiry was interviews conducted towards the end of their course; these lasted between 45 minutes to one hour and were recorded and transcribed. They were semi-structured, based on a topic guide that explored the following issues: interviewees' ideas for their businesses; the steps taken so far in starting their businesses; their perception of the resources and support needs of older women (in relation to younger women and older men) in establishing a business; their awareness of the support and resources available; and their future hopes and expectations for themselves and their businesses. In spring and summer of 2012 follow up interviews were conducted with 20 of the original interviewees who agreed to share their experience 3-5 years on. 
Forty-five women in the 50+ category agreed to take part in the original interviews. Of these nine were already self-employed (in businesses including design, alternative therapy, training and consultancy). Over half of the remainder were not currently economically active; the rest worked in a variety of part-time or full-time jobs. Their employment backgrounds included architecture, social work, teaching, administration, management, child-minding, dressmaking and design, nursing and retail. Their countries of origin included France, Nigeria, Hong Kong, India, Sri Lanka, Venezuela and Argentina as well as the UK. Our interviews did not set out to elicit narratives but, as Riessman (1993, p. 56) points out 'almost any [interview] question can generate a narrative'. When interviewees respond to a question with a story they take on extra responsibility for meaning making (Hollway \& Jefferson, 2000); the stories that emerged therefore formed promising material with which to investigate 'how people create meanings out of events in their lives' (Chase, 2008, p. 70). All the transcripts of the original interviews were read and re-read in order to extract their narrative elements; following Coffey \& Atkinson (1996), Ibarra \& Barbaslescu (2010) and Brown et al (2009) we did not separate stories from narratives, but understood these elements as comprising any accounts in which interviewees drew on past experience. These accounts were collected, coded and grouped according to the recurrent themes and plots found across them.

We then examined more closely the narratives found in interviews with the 36 women without recent experience of self-employment. Our reading iterated between paying attention to form - the ordering of events and experiences, and content - the events around which the story was constructed, their location in time and space, the key actors involved and their part in events. We made understanding the purpose of these narratives the main focus of our analysis (Coffey \& Atkinson, 1996); applying aspects of the schema suggested by Beech \& Sims (2007) - identifying the causal connections established between events; the attribution 
of agency, emotion and responsibility to self and other; the construction of separations and oppositions - in order to locate meaning within our participants' stories.

\section{Narratives of continuity and validation, change and agency}

Analysis of narratives used by the 36 participants to explain and justify their pursuit of selfemployment revealed four distinctive themes. Illustrative quotations from each are provided in Table 1. The most frequently used theme was that of continuity. Participants typically stressed the length of time that their story encompassed; often signalling this emphasis with the word 'always'. Consistency and continuity were further reinforced by eliding past and present tenses - from 'I have always...' to 'I am'. We understand these narratives as intended to convey the sincerity of the narrators' intent; rendering their interest in selfemployment, not as a passing fancy, but as expressive of an on-going, authentic, but as yet unfulfilled identity. Furthermore, the stress on independence, and the use of the imagery of 'dreams' and 'vision', illustrated here, all resonate with aspects of the enterprising ideal. While narratives of continuity typically emphasised the consistency of their interest in selfemployment, narratives of validation (illustrated in the second set of quotations in Table 1) recounted events and experiences - from across their life course and from both within and outside the workplace - that offered evidence of their capacity to act on this interest. These stories often gave a prominent position to other actors, whose testimony supported their claims to possess entrepreneurial capabilities.

By emphasising a long-standing identity, narratives of continuity (often supported by those of validation), raised implicit questions as to why the narrator had left it until now to engage with self-employment. The second most frequently applied narratives were therefore those involving change (the third set of quotations in Table 1); indicating shifts in participants' 
priorities and outlook that made independence and autonomy now even more important to them. References to having reached a 'stage', or 'point' in life reflect models of women's life-stages; the idea that they were now at a point of transition supported participants' account of self-employment as a positive and appropriate choice by making it the outcome of a process of development.

When participants responded to a question with a story, these stories were characterised by self-representation as an active agent - recounting the decisions that they had made in response to challenges encountered across their life course. So in addition to narratives of 'natural' and progressive change we found stories that explained their current engagement with self-employment by offering accounts of recent unwelcome or unexpected events or experiences. Participants made these experiences the pivotal point of their stories, reformulating them as learning opportunities and integrating them into tales of recovery and increased resolve. We understand these accounts (illustrated by the third set of quotations in Table 1) as narratives of agency.

[insert Table 1 about here]

\section{Expressing self-doubt, ambivalence and pessimism}

Participants typically drew on more than one of these narratives - woven together or offered at different points during the interview - as they sought to construct a coherent and convincing account of why self-employment was now an appropriate trajectory. Yet reading the transcripts also revealed, across many interviews, expressions of self-deprecation, ambivalence or doubt which had the effect of moderating the optimism conveyed by their justifying and supporting narratives. Although self-deprecation (examples of which are given in the first set of quotations in Table 2) helped to explain their presence on the course as a 
means to develop self-confidence and business skills, references to a lack or loss of assertiveness or self-esteem seemingly undermined the representation of the self (offered in narratives of continuity and validation) as capable and focused - thus distancing them from the enterprising ideal.

[insert Table 2 about here]

Exploration of expressions of doubt and ambivalence revealed that many made direct reference to the question of older age (illustrated in the second set of quotations in table 2). Participants' references to their age as problematic suggested that they now had fewer options available to them, reflecting the processes whereby older workers become positioned as organizational outsiders - cast as more inflexible or resistant to innovation, and the subjects of discriminatory practices. These expressions can be contrasted with narratives of change (illustrated in Table 1) which, by associating a shift in priorities with achieving a life stage, also engaged with the question of age. These narratives offered an alternative construction on the interplay of age with an organizational outsider position. They suggested an emergent identity as a free-spirited person increasingly less amenable to organizational control - in alignment with the enterprising self, and supporting the idea of self-employment as a positive alternative to working for others.

\section{Narrating self-employment - five individual vignettes}

We consider further how these narrative themes were deployed, and their effects in constructing a provisional, self-employed identity, through a more in-depth examination of the accounts of five participants, selected from amongst the 20 women who participated in both the initial phase and the follow up interviews; thereby enabling reflection on their original identity work in the light of subsequent developments. The five individuals were 
chosen because analysis of the accounts in their original interviews revealed contrasts in the way that they engaged with their age in relation to their plans for self-employment. Their interviews provide an interesting variety of narrated experience with which to review and develop conceptual understandings of the interplay of age and gender with enterprise. Background information on each interviewee is presented in Table 3.

[insert Table 3 about here]

\section{Colette - assuming an ageing identity}

Colette's account was unusual in that the ageing identity that she threaded into her stories incorporated, rather than resisted, the idea of decline. Her interview revealed a tension between self-employment as something she wanted to do, and as something enforced upon her. Having been 'wondering for some time, whether there was a different way of earning a living besides being employed...' she had found out that she was to be made redundant, leading her to react: 'fine, decision made for me!'

Colette explained that after abandoning a teaching career early on she had worked in various jobs in private, public and voluntary sector organizations. Her reflections on her work history led her to claim that she had always been something of an organizational outsider: 'I've never been anywhere very long, 7-8 years at the maximum so I'm starting to wonder whether that's not another reason for trying to work for myself maybe I'm just not very institutional-isable! [laugh]' - before providing an account of a recent event that had further prompted her:

'one of my brother-in-law died last year, he was young - I just want to spend more time with [my family] and enjoy them before it's too late - and enjoy myself before it's too late, I do 
realise I'm starting to lose fitness and flexibility and - I've always enjoyed mostly doing physical things so I want to do some more of that before I slow down completely...'

Although Colette's anticipation of physical decline supported the idea that now was the right time to act, she also told us she would have liked to work for longer to secure a better pension, but that the only alternative post her organization offered: 'meant a lot of [international] travelling - I don't want to do that anymore... Can't do it, won't do it - but again in a way that forced me towards making a decision in favour of going self-employed because I realised what else is there?' So, in the course of her interview, Colette represented herself not only as someone less physically flexible, but also more selective regarding the work tasks she was willing to undertake. These attributes helped make sense of a move out of employment, but by adopting them Colette risked making her entrepreneurial spirit more a feature of her past than of her present identity.

\section{Mary - refusing an older identity}

Mary had recently trained as a hypnotherapist in order to pursue the idea of self-employment, an idea she had: 'always toyed with... throughout my working life... there must be another way to have a bit more control and a bit more flexibility'. However her whole career had been spent in the public sector because: 'I didn't really have much choice; I was a single parent... I really had to get the very best paid job I possibly could'. She also was undergoing redundancy and now wanted to earn a living in a way that: 'wouldn't be dependent on personalities at work, restructurings, reviews, retirement issues - because this is actually the second time I've been made redundant.' Yet she recognised her ambivalence towards abandoning organizational employment altogether: 'I can't keep myself away from the 
Wednesday Guardian [newspaper] when public sector jobs come up... I just think it would be nice to have that regular pay check coming in... and somebody paying into the pension'.

When asked to reflect on issues relevant to older women Mary exclaimed: 'I'm not even sure if I totally identify with the older woman! [laugh] I have noticed and appreciated throughout the course when [tutors] have put up signs directing us around the building because it is a complicated building to get our heads round. I've... thought we must appear a very dopy lot! [...] I can see why government money is being spent on younger people... but by the time people get to $50 \mathrm{~s} .$. if they haven't sorted themselves out by then frankly are they going to? I think I still have a bit of that belief in me'.

Mary's refusal of the label 'older woman' echoes the observation that 'older worker' is a category based not on age but on perceived vulnerability. In her rejection, Mary reiterates a view of people over 50 as having become fixed in their thinking and acting. Yet by recognising that she is now a member of that group she brings into question her own commitment to undertaking a major change in her working life.

\section{Marilyn - aged but not ageing?}

Marilyn also intended to become a self-employed therapist explaining that: 'I've always been very much into alternative therapies but on the receiving end. I've had a monthly massage for the last twenty years, I meditate regularly, I am always going on yoga weekends...' However she went on to make a growing disillusionment with the workplace the focal point of her story of self-employment: 'about five or six years ago I started thinking that I was feeling quite burnt out in the job that I was doing.' Her story took a yet another turn when she recounted the traumatic event that had forced her out of a job (in mental health support) that 
she had 'loved': 'Loved every second of it and done it for years and years and years and would never have left... but I had an incident with somebody who I maybe just let my guard down and I lost my confidence, I couldn't go into anybody's house. Because this person had barricaded me into their home'. Yet despite seeming reluctant to forgo completely the identity of committed professional, she later reinforced the theme of disenchantment with employment explaining: 'I have reached a point where... I am impossible to manage. Because I think what happens is, we have an idea... we run our own lives; you reach a point where you don't want anyone telling you what to do'.

When, in the preceding account, Marilyn shifted from ' $\mathrm{I}$ ' to 'we' and 'you', she suggested that becoming less tractable was something she shared with other women at the same point of life. But she later made a point of differentiating herself from women of her age, telling us: 'both of my daughters who are in very high-powered jobs tell me... that I am inspirational... they say lots of their friends' mums are not... they will be sitting indoors watching the telly and maybe saying well, this is it'. Marilyn drew instead upon her working-class roots as a point of identification with the biographies of famous entrepreneurs:

'A lot of people in business who have been very, very successful... have come from quite humble backgrounds... people are able to totally turn their lives around without all of that extra support... You've just got to have the dream, the determination and the guts'.

\section{Temi - age as a problem for other people}

Temi was contemplating taking redundancy or early retirement. She recounted a recent incident that had strengthened her resolve to leave. In her story she implied that her age made her something of an organizational anomaly, provoking: 'a clash with one of my 
business unit heads... I don't know whether it was envy or jealousy... because some people can't handle that this person is older than me... I thought you know what? I could actually do this working for myself'. Temi stressed however that wanting to leave was not a response to recent events but an expression of an on-going entrepreneurial identity. In similar fashion to Marilyn she grounded this identity in her roots - her family, and her Nigerian heritage, through the following story: 'When I was going to secondary school... I went to the market and I saw these yams... I bought some and I went back to school and somebody said that's a nice yam and I said well, I can get you some, I bought some, lowered the price and sold it to them. So when I told my mum she said 'that's crafty but that's my girl!'

Temi agreed that older women, when compared to older men, risk not being taken seriously as potential business people. However her response to any questioning of the wisdom of her starting a business at her 'present age' was to assert: 'I can't just sit there, I've got to do something and this is what I want to do. Working for me is a passion that has always been there and this is it'. Temi based her sense of purpose in an on-going identity that over-rode the fact of her age. In so far as her position as an older woman represented an issue, it was one that mattered to other people - not to her.

\section{Naomi - defying age and gender stereotypes}

Naomi had recently qualified as a counsellor but had failed to find paid employment in that field. She and a female colleague planned therefore to set up their own counselling service. Naomi had left her last paid post in response to the frustrations of working in local government where: 'it was bashing my head against a brick wall to get the slightest thing done... And one day I just reached some kind of plateau with it ... and I just thought that's it, 
I am off, I am going'. This coincided with her husband retiring and they took six months off 'to travel and do all the things that we paid for our kids to do before they went to university'.

Naomi did not regard self-employment as something she needed to do to make money, but because: 'I need a purpose in life... financially yes, we could get by.... but I need a reason to get up every day'. She strongly resisted any suggestion that because she was not driven by a financial imperative, she wanted to start a business as a sort of hobby. So when one of her husband's friends had said: 'you need something to keep you busy' her reaction had been: 'I thought I'd slap him, bloody bastard.... how many other people think that I am ... financially stable so just a little job for the little lady indoors and that old rubbish'. Anger also featured in her account of failing to find a counselling job: 'That really stank. Because I thought is it because I am fifty... I know you are not supposed to have that [discrimination] with equal opportunities but they bloody do'. Naomi's anger seems to strengthen her purpose and resolve, drawing on an identity as an older woman as a position from which to challenge and defy age and gender stereotypes.

\section{Discussion: negotiating self-employment}

The formulation of opting in (to self-employment) and opting out (of organizational employment), when applied to mid-life professional women or mumpreneurs (McKie et al, 2013; Ekinsmyth, 2013) renders the former a positive choice and a viable alternative. Each vignette contains an account of having become marginalised in, or excluded from the workplace; most women in our study found themselves in a situation where employment had become more inaccessible to them through circumstances not of their choosing. In this context the function of their identity work can be understood, not only as accounting for their present interest in self-employment, but as supporting, claiming or recovering a positive and 
valued sense of self. Conceiving of self-employment as an alternative path allowed them to envisage a future of continued, purposeful engagement; it required of them that they craft and project an identity as a person sufficiently proactive and self-reliant to be able to pursue it. These vignettes reveal that a provisional self-employed identity was constructed, not in isolation, but in relation to other possible identity positions; encompassing an organizational outsider identity, an aged identity and an enterprising identity. We contrast the forms of interplay between these identities found in participants' accounts and highlight points of apparent tension, before considering their implications for enacting self-employment.

The centrality of choice and agency is evident in a frequently used narrative form, (illustrated here by the stories of Colette and Marilyn) in which interviewees first stressed their on-going interest in self-employment before recounting the events that had impelled them out of their jobs. This chronological ordering enabled them to resist an imposed identity as an organizational outsider, asserting instead a provisional self-employed identity as an authentic expression of who they felt themselves to be. Yet the interviews also revealed varying degrees of disengagement from organizational employment. Marilyn's continuing attachment to a job that she was forced to leave raised the question whether a provisional identity as selfemployed therapist served as an adequate substitute, echoing the finding of Riach and Loretto (2009), that a previous working identity can still be an important part of self-identity, even if no longer enacted. The competing threads of her story indicate the tension between narratives of continuity that sustain authenticity and consistency (true to the person I have always been) and narratives of agency (of choosing another path). Marilyn resolved this tension by introducing an aged identity into her story of self-employment - reinforcing her disengagement from the workplace by associating becoming a less 'manageable' employee with reaching a 'point' in life. In similar fashion Colette reinforced her intention to pursue self-employment by incorporating ageing into her account; in her story her awareness of time 
passing added to the sense of urgency; whereas Temi and Naomi's interviews illustrate yet a further use of age as a narrative element - in stories where the negativity of others towards their older status, rather than any failings on their part, provided the explanation for their marginalisation or exclusion from the workplace.

Although in each case age was applied rather differently, the effect of making age the plot of her story was to cement the narrator's position as organizational outsider. Whilst this positioning supported their interest in becoming self-employed, in so far as their accounts involved self-representation as a more difficult, less flexible, or more unwelcome employee, then they also implied an alignment of the organizational outsider position with the negative associations of an older worker identity. These associations, which echo those of the 'vulnerable senior', or non-ideal ageing subject (Rudman, 2006), are apparent in accounts such as those of Mary and Marilyn that raised the spectres of passivity, dependence and enfeeblement. They raised these spectres in order to distance themselves from them - so that the dominant self-representation of the self in relation to age was that of undiminished activity; even Colette's 'before it's too late' story, although explicitly referencing physical change, was formulated in relation to an on-going identity as an active person. It is interesting to note where asserting an active identity had a gendered, as well as an aged, dimension - exemplified by Naomi's and Marilyn's refusal of passivity associated with confinement 'indoors' - that self-employment offered the means to continued engagement in the public sphere even if other opportunities were denied to them.

Mary and Marilyn engaged with an aged identity by refusing less desirable attributes of an older identity for themselves while allowing them for others - a familiar age-denying strategy that accepts rather than challenges the negativity attached to membership of an older category. In contrast, Naomi and Temi's engagement with external attitudes towards older women involved them in resisting, not their age, but ageism. Not only did this permit more possibility 
of solidarity with other women, but the insertion of a sense of injustice into their narratives seemed particularly productive of agency and purpose. By representing themselves as reacting against external constraints they took on a more active protagonist role - echoing the argument of Ibarra \& Barbulescu (2010) that narratives that engage the storyteller in repeated agency assist in the construction of a consistent and authentic self.

'Good stories' introduce and order events so that they lead inexorably to their conclusion, which for our participants was deciding to pursue self-employment. Self-positioning as organizational outsider supported this decision; but they also needed to convey that they had the potential to succeed in working independently. This engaged them in crafting stories that rendered past experiences relevant and meaningful in the light of their present aspirations - as providing evidence of entrepreneurial attributes such as passion, capacity for hard work, and adaptability. And when participants recounted stories such as that of Temi that drew on events from their childhood or young adulthood, it may be assumed that they considered this material still relevant to the person they were in the present - as expressive of a continuing, undiminished capacity for enterprise.

Such stories construct an enterprising identity as inherent, rather than acquired later in life; the notion of enterprise as an intrinsic characteristic also helped to distinguish the narrator from others around her - thus Temi and Marilyn drew on their ethnicity and class to make an entrepreneurial identity their own, enabling them to apply to themselves some familiar entrepreneurial tales such as 'from rags to riches'. Colette's overview of her work history supported her claim to be an independently-minded person; however the continuing relevance of this account was brought into question by her other stories, which introduced an older self. So while an aged identity can support an organizational outsider position, it puts an enterprising identity at risk, disrupting the narrator's efforts to establish coherence and consistency over the life course. 
But participants in our study needed to provide narratives of change in order to explain why they had left it until now to pursue their interest in self-employment. More optimistic accounts described reaching a turning point, or a new stage in life associated with greater freedom (from domestic responsibilities), more self-knowledge and reordering of personal priorities, and (for some women) greater personal or financial security. But although these narratives suggest a more positive view of women's ageing that (in line with Krekula's (2007) argument) references personal growth and development, the elements involved are not equally available to all women. In addition to the impact of redundancy and restructuring, women in our study were variously affected by divorce or separation, new caring responsibilities, ill-health, or periods away from employment, which proved harder to weave into a positive and hopeful story. But whatever their individual circumstances, the identity work of women across our study was largely concentrated on recovering or discovering a capacity for enterprise that they experienced as latent, dormant or suppressed rather than as something entirely new to them.

To summarise: a provisional self-employed identity offers a means to resist a vulnerable, ageing position associated with dependence and increased passivity; it is strengthened by asserting an inherent, on-going capacity for enterprise. An aged identity can support a selfemployed identity through the idea of being at a transitional point in life, but threatens it through the association of older age with an imposed organizational outsider identity. Resisting the imposition of a marginalised position that offers little scope for choice and agency involves in turn distancing the self from an older identity. But rather than manifest a blanket of denial, these vignettes illustrate the variation found in both the form and extent of participants' disengagement from a position in the 'older woman' category. 


\section{Enacting self-employment}

The suggestion that constructing a provisional self-employed identity served a reparative function for our participants raises questions about the seriousness of their intent and their determination to succeed - questions that concern whether they would take forward their business plans. We earlier noted expressions of ambivalence, doubt or pessimism that seemed to undermine their commitment to the enterprising ideal. Engaging in provisional identity work involves trying out different story lines as part of an evolving repertoire of accounts appropriate to different contexts and audiences; it is unsurprising that the narratives of our participants were not always consistent or entirely coherent. Moreover, as Ibarra \& Barbulescu (2010) argue, having only one consistent narrative imposes more constraints upon the individual to live up to the provisional identity that is claimed by that narrative. Viewed from this perspective, participants' expressions of ambivalence reflect the risks involved in making a strong investment in self-representation as entrepreneurial. Not only might they find it difficult to implement their plans, but over-commitment to one particular path might close off alternative possibilities of being and acting.

So rather than see ambivalence as evidence of insufficient engagement with the demands and expectations of enterprise culture, it may manifest a wish to keep open other opportunities to attain independence, enhance self-worth or build a secure financial future. The narratives discussed here were produced at a time when the participants did not know how their story of transition would end; we summarise below what the five individuals told us, 3-5 years later, about what happened to their plans for self-employment; reflecting very briefly on the outcomes in the light of certainties, uncertainties and tensions that they expressed in their original interview. 
After some initial success Colette was unable to take her business further in a difficult economic climate. She and her husband had bought and renovated an old house and garden further out of London, where they were active in local groups and campaigns. She told us that I'm not bored at all - the only issue is that I'm not earning anything'. She had not completely abandoned her business plans, but she had started applying for jobs - so far without success. Colette's life style reflected something of the future she had envisaged in her interview, but the identity of 'active retiree' was one imposed upon her prematurely - and without the financial security to support it.

Colette's experience bears out the concerns that she and Mary had expressed regarding the financial impact of leaving their jobs - concerns that don't accord well with the risk-taking norms of enterprise, yet make clear that organizational employment can offer better protection from the vulnerabilities of ageing. Mary had abandoned the idea of becoming a hypnotherapist; instead she had managed to secure a series of fixed-term posts with the same employer, which she considered 'these days is quite an achievement... but it's always very dicey'. She combined full-time employment with 'more interesting' freelance work for a community development project. She was now filing her own tax returns, which she regarded as evidence that she was moving towards 'being self-employed'. Although Mary had not completely discarded a self-employed identity, her sense of achievement at still having a job confirms that the protection that employment provides is not only financial; it had enabled her to prolong the deferral of an identity as an 'older woman' that she had refused in her earlier interview.

Marilyn, having left employment in order to practise as an alternative therapist, survived a difficult period of 'four months with no money'. She returned to do some part-time work for her previous employer, but did not mean to continue when her contract expired - intending instead to concentrate on her business. She supplemented her income by offering bed and 
breakfast and considered herself 'in a better financial position than I've ever been'. Marilyn's continuing engagement with paid employment reflects the incompleteness of her disengagement from the workplace that she had originally conveyed, but - as in her original interview - she continued to assert the primacy of self-employment over organizational employment in shaping her future plans.

Temi had left her job with an early retirement package. She had undergone a tough initial six months getting consultancy contracts with small companies - which had in some cases turned out to be poor payers. Although her business was not yet 'paying the bills' she told us 'I am enjoying it... it gives me a buzz'. She supplemented her income by renting out property. Temi's reference to a 'buzz' continues the theme of 'passion' that she had earlier expressed when asserting her commitment to enterprise, and which seemingly sustained her efforts to develop her business, despite setbacks and disappointments.

Naomi worked as a counsellor in private practice and ran a low cost counselling service with her female business partner. Their company had won its first major contract via membership of a consortium bid; despite their present low earnings she told us 'I'm just not giving up now - we are so close to making some proper money - although it's not about the money for me... it's about doing it'. Naomi emphasised how the complementary skills of her partner and herself had helped them to establish their business - offering a story of self-employment that, by highlighting interdependence, diverges from the idea of the autonomous, enterprising self.

\section{Concluding reflections}

These brief reflections on interviewees' subsequent trajectories invite further consideration of the implications - for their realisation and enactment - of provisional identities constructed 
according to relatively consistent narratives that reinforce authenticity and sustain the sense of purpose, as opposed to identities constructed through more ambivalent or ambiguous narratives that are more capable of being reworked according to changing circumstances. The study reported here was not designed to elicit narratives; the stories on which we draw are thus variable and often fragmented, making systematic comparison across interviewees and across interviews more difficult, but it offers a framework of ideas to inform further longitudinal research into the relationship between the narration of possible future selves and their accomplishment.

The plans of women in our study were adversely affected by the aftermath of the 2008 financial crisis; none of the five women whose accounts are explored here had yet established a financially sustainable business. But determining whether or not this constituted a failure on their part to realise an enterprising identity is not straightforward because of the confusion of ideas concerning self-employment, entrepreneurship and the enterprising self. Toynbee (2014), noting the rapid rise in UK self-employment, particularly amongst the over 50 and over 65 age groups, disputes claims that these are 'thrusting [sic] entrepreneurs' arguing that the driver is the lack of available alternatives. So although not 'entrepreneurs' in the classic sense, more and more people (of all ages) are required to be 'enterprising' in the sense of having to find and manage their own work. The idea of a universally accessible enterprising self contrasts with the assumptions, applied by our participants to themselves, of enterprise as a set of inherent characteristics which, by implication, are not shared by everyone. Arguably this more exclusive model of enterprise supported our participants' efforts to establish a distinctive and valued sense of self, but it may be asked how far all the different forms of self-employment with which people increasingly engage require them to internalise the ideals and values of enterprise. This study confirms that the enterprising self is an ambiguous and 
contested concept; highlighting the need to develop deeper and more nuanced understandings of its relevance to different groups and contexts.

Finally, given increased life expectancy and the continued postponing of the official retirement age, it can be asked on what basis women in their 50s are marked out and placed in an 'older' category. It could be argued that the aged identity that our participants were invited to discuss was one imposed upon them by the research process, and one that carried assumed negative and problematic associations. These associations invite resistance, denial or the production of alternative, 'positive' accounts of an older identity. The concept of the olderpreneur offers an alternative to the negative portrayal of older age, but perpetuates the division of people into arbitrarily assigned categories of age. The varied life experiences, circumstances and aspirations of the women in our study confirm that it is inappropriate to make generalised statements about their needs, or about the particular advantages or disadvantages they share. This consideration suggests that a preoccupation with age has limited value in exposing the factors that enable people to initiate independent working successfully - the barriers they face, the resources and support they need. But alongside an appreciation of the irrelevance of age, this paper offers a perspective on its relevance understanding age not as a set of characteristics, but as a process. This understanding invites further exploration of how individuals make use of chronology in their narrative identity work - how they interweave the passing of time into their accounts of the self in the past, present and future.

\section{Acknowledgements}

We thank Cynthia Hardy and two anonymous reviewers for their insightful comments and suggestions in revising and developing this paper. The research team that carried out the 
study described here comprised Fiona Colgan, Hilary Farnworth, Kiran Kalsi, Ann Reynard and Frances Tomlinson.

\section{References}

Ahl, H. (2006). Why research on women entrepreneurs needs new directions. Entrepreneurship Theory and Practice, 30, 595-621.

Ainsworth S (2002). The 'Feminine Advantage': a discursive analysis of the invisibility of older women workers. Gender Work and Organization, 9, 579-601.

Ainsworth S \& Hardy C (2004), Critical discourse analysis and identity: why bother? Critical Discourse Studies, 1: 225-259.

Ainsworth, S. \& Hardy, C. (2008). The enterprising self: an unsuitable job for an older worker. Organization, 15, 389-405.

Alvesson M., Lee Ashcraft K., \& Thomas R (2008). Identity matters: reflections on the construction of identity scholarship in organization studies. Organization, 15, 5-28.

Austen, S. E., and Ong, R. (2009). The employment transitions of mid-life women: health and care effects. Ageing and Society, 30, 207-227.

Bachelor, L. (2013) Self-employed worker numbers soar in the UK. The Guardian, $6^{\text {th }}$ February.

Beech, N. \& Sims, D. (2007) 'Narrative methods for identity research' in Pullen, A., Beech, N. \& Sims, D. (Eds.) Exploring Identity: Concepts and Methods. (pp. 288-301) Basingstoke, Hampshire: Palgrave Macmillan.

Bohlinger, S. \& van Loo, J. (2010). Lifelong learning for ageing workers to sustain employability and develop personality. In CEDEFOP, Working and ageing: emerging themes and empirical perspectives (pp. 28-57). Luxembourg: Publications Office of the European Union. 
Bourne, K. A., \& Calás, M. B. (2013). Becoming 'real' entrepreneurs: women and the gendered normalization of 'work'. Gender, Work and Organization, 20, 425-438.

Brown, A., Gabriel, Y, \& Gherardi, S. (2009). Storytelling and change: an unfolding story. Organization, 16, 323-333.

Bruni, A, Gherardi, S. \& Poggio, B. (2004). Doing gender, doing entrepreneurship: an ethnographic account of intertwined practices. Gender, Work and Organization, 11, 407-429. Chase, S (2008). Narrative inquiry: multiple lenses, approaches, voices. In N. Denzin, and Y. Lincoln (Eds.) Collecting and Interpreting Qualitative Materials. (pp. 57-8) Thousand Oaks: Sage.

Cobley, P. (2001) Narrative. London: Routledge.

Coffey, A. \& Atkinson, P. (1996) Making Sense of Qualitative Data: Complementary Research Strategies. Thousand Oaks: Sage.

Coupland, C., Tempest, S. \& Barnatt, C. (2008). What are the implications of the new UK age discrimination legislation for research and practice? Human Resource Management Journal, 18, 423-431.

Duncan, C. \& Loretto, W. (2004). Never the right age? Gender and age-based discrimination in employment. Gender, Work and Organization, 11, 95-115.

Ekinsmyth, C, (2013). Managing the business of everyday life: the roles of space and place in 'mumpreneurship'. International Journal of Entrepreneurial Behaviour and Research 19, $525-546$.

Elliott, J. (2005). Using Narrative in Social Research: Qualitative and Quantitative Approaches. London: Sage.

Essers C \& Benschop Y (2007). Enterprising identities: female entrepreneurs of Moroccan or Turkish origin in the Netherlands. Organization Studies, 28, 49-69. 
Fenwick, T. (2002). Transgressive desires: new enterprising selves in the new capitalism. Work, Employment and Society, 16, 703-723.

Gabriel, Y., Gray, D. \& Goregaokar, H. (2010). Temporary derailment or the end of the line? Coping with unemployment at 50. Organization Studies, 31, 1687-1712.

Hart, M. (2007). Senior Start-ups Study. London: Yell.com/Small Business Centre, University of Kingston.

Hodges, J, (2012). The transition of midlife women from organizational into selfemployment. Gender in Management, 27, 186-201.

Hollway, W., \& Jefferson, T. (2000). Doing Qualitative Research Differently. London: Sage. Ibarra, H. \& Barbaslescu, R. (2010). Identity as narrative: prevalence, effectiveness, and consequences of narrative identity work in macro work role transitions. Academy of Management Review, 35, 135-154.

Jyrkinen, M,. \& McKie, L. (2012). Gender, age and ageism: experiences of women managers in Finland and Scotland. Work, Employment and Society, 26, 61-77.

Kautonen, T., Luto, S., \& Tornikoski, E.T., (2010). Influence of work history on entrepreneurial intentions in 'prime age' and 'third age': a preliminary study. International Small Business Journal, 28, 583-601.

Krekula, C. (2007). The intersection of age and gender: reworking gender theory and social gerontology. Current Sociology, 55, 155-171.

Kibler, E., Wainwright, T., Kautonen, T. \& Blackburn, R.A. (2012). (Work)life after work? Older entrepreneurship in London - motivation and barriers. London: Kingston University Small Business Research Centre.

Lewis, P. (2013). The search for an authentic entrepreneurial identity: difference and professionalism among women business owners. Gender, Work and Organization, 20, 252266. 
Lewis, K., \& Walker, E.A. (2011). Self-employment: Policy panacea for an ageing population? Small Enterprise Research, 18, 143-151.

Loretto, W. \& White, P. (2006). Employment of older workers: employers' attitudes, policies and practices. Human Resource Management Journal, 16, 313-330.

Marlow, M. \& McAdam. M. (2013). Gender and entrepreneurship: Advancing debate and challenging myths; exploring the mystery of the under-performing female entrepreneur.

International Journal of Entrepreneurial Behaviour \& Research, 19, 114 - 124.

McKie, L., Biese, I., \& Jyrkinen, M. (2013). 'The best time is now!': the temporal and spatial dynamics of women opting into self-employment. Gender, Work and Organization, 20, 184196.

Moore, S (2009). No matter what I did I would still end up in the same position: age as a factor defining older women's experience of labour market participation. Work, Employment and Society 23, 655-671.

OECD, (2012). Policy brief on senior entrepreneurship: entrepreneurial activities in Europe Luxembourg: Publications Office of the European Union.

Riach, K. (2007). 'Othering' older worker identity in recruitment. Human Relations, 60, $1701-1726$.

Riach, K. (2009). Managing 'difference': understanding age diversity in practice. Human Resource Management Journal, 19, 319-335.

Riach, K., \& Loretto, W. (2009). Identity work and the 'unemployed' worker: age, disability and the lived experience of the older unemployed. Work, Employment and Society, 23, 102119.

Ricoeur P (1991) Narrative Identity. In D. Wood (Ed.) On Paul Ricoeur. (pp. 188-199) Oxford: Routledge.

Riessman, C.K. (1993) Narrative Analysis. Thousand Oaks CA: Sage. 
Rudman, D. L. (2006). Shaping the active, autonomous and responsible modern retiree: an analysis of discursive technologies and their links with neo-liberal political rationality Ageing and Society, 26, 181-201.

Š́mová, Z. (2010). To work or not to work: motivation for work after reaching retirement age In CEDEFOP, Working and ageing: emerging themes and empirical perspectives (pp. 169189). Luxembourg: Publications Office of the European Union.

Storey, J., Salaman, G., \& Platman, K. (2005). Living with enterprise in an enterprise economy: freelance and contract workers in the media. Human Relations, 58, 1033-1054.

Toynbee, P. (2014). Help to Work is a costly way of punishing the jobless. The Guardian $15^{\text {th }}$ April 2014.

Walker, H., Grant, D., Meadows, M., \& Cook, I. (2007). Women's experiences and perceptions of age discrimination in employment: implications for research and policy. Social Policy \& Society 6, 37-48.

Wee, L. \& Brooks, A. (2012). Negotiating gendered subjectivity in the enterprise culture: metaphor and entrepreneurial discourses. Gender, Work and Organization, 19, 573-591.

Yuval-Davis, N. (2006). Intersectionality and feminist politics. European Journal of Women's Studies, 13, 193-209. 
Table 1. Examples: narrative themes of continuity and validation; change and agency.

\section{Continuity}

I've always been an independent sort of minded person. I want to do things my own way....

Sitting being a part-time typist has been always very frustrating and I've had lots of ideas... I have an imagination...

I have been wanting to be self-employed probably longer than I realised. Because I am quite a creative, independent person and I actually do quite well when I get jobs where I start something up....

I wanted to be creative all this time so since I started having my family and since I had this business, years ago...

Thirty-three years ago I came to this country with two suitcases not knowing where I was going to live and not having a job....there is... part of me that just goes for things so I have visions and I hang on to them and I go for it...

The idea of creating my own business.... and give them as a heritage to my family was my dream from very long time ago...

\section{Validation}

People were coming back [for aroma therapy] because it did them good...

I went in as the manager for that service last year and set up the service, helped them to market the service, get the patients in and developing the systems and documentation to make that work....

His (husband) view is that if I can work that hard for somebody else I should be able to work that hard for myself...

I've always been quite precise and organised and these are skills I've developed from being a mother, from being a home maker, from juggling work, home, children, friends....

I've been involved in the PTA of the school... it's been quite successful because I am good at dealing with people...

The only business thing that I've ever done was to sell bags of sweets in the school playground.... I was chuffed that I had some money....

\section{Change}

I started off working for other people and now want to do it for myself....

It suits me at this stage in my life. Work-life balance is more important to me....

I just reached a point in my life... where my children have just about left home and I just felt ready to be able to commit myself to something now...

I am getting older, I want to do something that's lighter, more fun and use all the skills that I have from my profession...

I think it's more to do with my age really... I want to do my own thing and I don't want people to control me any more...

So my husband had a fantastic salary for a while. He's now retired and I do need to work and I want to prove some of my ideas

\section{Agency}

Having a terrible manager ... he treated me shockingly bad. And after that day I thought I am never ever let someone like that treat me like that again... It's almost like the catalyst maybe...

And also last year I was made redundant, got a good pay-off, paid off a lot of my debt. And I thought I've got to look, this is a good opportunity now to work for myself....

I wasn't enjoying my job....And then I read a book called Rich Man, Poor Man and that kind of changed everything for me, this book. So I just thought I would try and set up a business...

I used to go on walking groups and walking holidays and I was quite frustrated that people didn't tell me about the area that I was walking through and I thought I can do this better. And so I decided to try it for myself.... 
Table 2. Examples: expressions of doubt and pessimism.

\section{Self-deprecation and doubt}

I started selling French books and magazines to mothers with children so...I've always done a little something... but never with much expertise...

As far as the actual business is concerned I think the skill I possibly most lack is selling myself....

I knew that I'm great with ideas, I know that I'm a good people motivator... But I'm rubbish at business, I'm rubbish with money...

I still think it's a good idea but I do question my skills at being able to bring it all together; there is a lot of people out there doing it, they've had lots more experience than I have...

In another life I would have liked to be an inventor but I don't have a technical or scientific background....

But I am not very confident and that is where I don't go further in my career....My lack of focus comes from a lack of confidence....

I gave up my work to raise a family and I've had to do serious catching up and lots and lots of study to get up to speed as to where I would have been had I not taken time off to raise a family....

\section{The impact of age and age discrimination}

It's fiercely competitive out there with a lot of young people with a lot of money, equipment and contacts...

I don't want to just set up as an interior designer because I think that would be incredibly difficult at my time of life because I have not got that many years ahead of me....

I think at this stage of my life it's not really feasible to go and retrain in something completely new... I've been out of the workforce... since 1994.... when you haven't progressed up the career ladder you are basically starting at the same salaries as eighteen year olds which won't pay the rent....

There were two people who interviewed me and they were both half my age ... I didn't get the job and I felt afterwards that it was probably because he didn't want somebody my age in the post... I think for women going over 50 seem to make you less noticeable... With a man it seems to be the other way round ... they become - some gravitas....their experience, professional experience, their years is something that is added - 
Table 3. Individual interviewees quoted in this paper.

\begin{tabular}{|l|l|l|l|}
\hline $\begin{array}{l}\text { Interviewee } \\
\text { (pseudonym) }\end{array}$ & Business idea/s & $\begin{array}{l}\text { Employment } \\
\text { background }\end{array}$ & $\begin{array}{l}\text { Employment status } \\
\mathbf{2 0 0 7 / 0 9}\end{array}$ \\
\hline $\begin{array}{l}\text { Colette: white, } \\
\text { French, married } \\
\text { without children }\end{array}$ & $\begin{array}{l}\text { Consultancy on } \\
\text { EU funding }\end{array}$ & $\begin{array}{l}\text { Teaching, sales and } \\
\text { marketing, } \\
\text { administration }\end{array}$ & $\begin{array}{l}\text { European funding } \\
\text { manager, university }\end{array}$ \\
\hline $\begin{array}{l}\text { Mary: white, } \\
\text { British, single, one } \\
\text { grown-up daughter }\end{array}$ & $\begin{array}{l}\text { Hypnotherapy; } \\
\text { freelance } \\
\text { community } \\
\text { development } \\
\text { work }\end{array}$ & $\begin{array}{l}\text { Local government, } \\
\text { housing and community } \\
\text { development }\end{array}$ & $\begin{array}{l}\text { Fund-raiser, emergency } \\
\text { services }\end{array}$ \\
\hline $\begin{array}{l}\text { Marilyn: white, } \\
\text { British, separated } \\
\text { with grown-up } \\
\text { children }\end{array}$ & $\begin{array}{l}\text { Alternative } \\
\text { therapy }\end{array}$ & $\begin{array}{l}\text { Housing support worker } \\
\text { in mental health }\end{array}$ & $\begin{array}{l}\text { Alternative therapy and } \\
\text { part-time administrator }\end{array}$ \\
\hline $\begin{array}{l}\text { Temi: black, } \\
\text { Nigerian, separated } \\
\text { with grown-up } \\
\text { children }\end{array}$ & $\begin{array}{l}\text { Consultancy and } \\
\text { training, quality } \\
\text { management }\end{array}$ & $\begin{array}{l}\text { Local government, } \\
\text { finance and revenue } \\
\text { collection }\end{array}$ & $\begin{array}{l}\text { Finance manager, local } \\
\text { authority }\end{array}$ \\
\hline $\begin{array}{l}\text { Naomith white, married } \\
\text { children }\end{array}$ & service & Support worker, police \\
\hline
\end{tabular}

